\title{
PENGARUH VARIASI RASIO MOL 4-METOKSIBENZALDEHIDA DAN SIKLOHEKSANON PADA SINTESIS 2-(4'-METOKSIBENZILIDEN) SIKLOHEKSANON MENGGUNAKAN METODE MICROWAVE ASSISTED ORGANIC SYNTHESIS
}

\section{(THE EFFECT OF 4-METHOXYBENZALDEHYDE \\ AND CYCLOHEXANONE MOLE RATIO VARIATION ON THE SYNTHESIS OF 2-(4-METHOXYBE NZYLIDE NE)CYCLOHEXANONE USING MICROWAVE ASSISTED ORGANIC SYNTHESIS METHODS)}

\author{
Elga Riesta Puteri dan Sri Handayani* \\ Fakultas Matematika dan Ilmu Pengetahuan Alam Universitas Negeri Yogyakarta \\ Jl. Colombo No. 1 Yogyakarta 55281 \\ "e-mail: handayani@uny.ac.id
}

\begin{abstract}
Abstrak
Tujuan penelitian ini adalah menentukan pengaruh variasi rasio mol dan rasio mol yang menghasilkan rendemen maksimal. Sintesis senyawa 2-(4'-metoksibenziliden)sikloheksanon dilakukan melalui reaksi kondensasi Claissen Schmidt dengan katalis $\mathrm{NaOH}$. Variasi rasio mol 4-metoksibenzaldehida:sikloheksanon yang digunakan adalah 1:1, 1:2, 1:4, 1:6, dan 1:8. Sintesis 2-(4'-metoksibenziliden)sikloheksanon menggunakan metode MAOS dibutuhkan waktu 120 detik. Senyawa hasil sintesis diidentifikasi menggunakan KLT, KLT scan, spektroskopi IR dan ${ }^{1} \mathrm{H}$ NMR. Hasil penelitian menunjukkan bahwa variasi rasio mol 4-metoksibenzaldehida:sikloheksanon berpengaruh pada sintesis 2-(4'-metoksibenziliden)sikloheksanon. Hal tersebut ditunjukkan dari perbedaan rendemen yang dihasilkan. Variasi rasio mol 4-metoksibenzaldehida:sikloheksanon 1:1, 1:2, 1:4, 1:6, dan 1:8 menghasilkan rendemen 2-(4'-metoksibenziliden)sikloheksanon secara berurutan 0\%; 59,272\%; 64,122\%; 46,782\%; dan $45,555 \%$. Rasio mol 4-metoksibenzaldehida: sikloheksanon yang memberikan rendemen maksimal adalah 1:4.
\end{abstract}

Kata kunci: sintesis, MAOS, 2-(4'-metoksibenziliden)sikloheksanon

\begin{abstract}
This research aims to determine the effect of mole ratio variation and mole ratio which produce maximumyield. Synthesis of 2-(4'-methoxybenzylidene)cyclohexanonewasdonethroughClaissen Schmidtcondensation withNaOHascatalyst. Variationof4-methoxybenzaldehyde:cyclohexanone mole ratio were 1:1, 1:2, 1:4, 1:6, and 1:8. 2-(4'-methoxybenzylidene)cyclohexanone could be synthezied using MAOS methods for 120 seconds. Synthesis product was identified by TLC, $T L C$ scan, spectroscopy IR, and spectroscopy ${ }^{l} H N M R$. The result of this research showed that the variation of 4-methoxybenzaldehyde:cyclohexanone mole ratio had an effect on the synthesis of 2-(4'-methoxybenzylidene)cyclohexanone. It was proven by the different of yields which have been produced. Variation of 4-methoxybenzaldehyde:cyclohexanone mole ratio 1:1, 1:2, 1:4, 1:6, and 1:8 produced 2-(4'-methoxybenzylidene) cyclohexanone 0\%; 59.272\%; $64.122 \%$; $46.782 \%$; and $45.555 \%$ in yields respectively. The mole ratio of 4-methoxybenzaldehyde:cyclohexanone which gives the maximum yield is 1:4.
\end{abstract}

Keywords: synthesis, MAOS, 2-(4'-methoxybenzylidene)cyclohexanone 


\section{PENDAHULUAN}

Saat ini telah banyak senyawa organik yang berhasil disintesis dari penggabungan molekul-molekul kecil menjadi molekul yang lebih besar melalui berbagai reaksi kimia. Berbagai modifikasi dalam sintesis dapat dilakukan, misalnya dengan memvariasi bahan awal, yaitu dengan memodifikasi gugus-gugus fungsional, atau mengganti dengan bahan lain yang setipe (Budimarwanti, 2009).

Dalam proses sintesis suatu senyawa, jumlah reaktan yang digunakan dapat berpengaruh terhadap senyawa hasil sintesis. Nurcahyo (2014) melaporkan bahwa rasio mol sinamaldehida : aseton berpengaruh terhadap rendemen senyawa sinamalaseton yang dihasilkan. Variasi rasio mol sinamaldehida: aseton 1:1, 1:5, 1:10, 1:15 dan 1:20 menghasilkan rendemen senyawa sinamalaseton berturut-turut 7,269\%; $29,810 \%$; $54,530 \% ; 22,443 \%$ dan $9,411 \%$. Handayani dan Arty (2008) mensintesis beberapa senyawa dengan rasio mol aseton:benzaldehida dan turunannya (1:1) menghasilkan benzalaseton, anisal-aseton, veratralaseton dan sinamalaseton. Sedangkan dengan rasio mol aseton : benzaldehida dan turunannya (1:2) menghasilkan dibenzalaseton, dianisalaseton, diveratralaseton dan disinamal-aseton. Yuliyani (2016) memaparkan bahwa ada pengaruh variasi rasio mol sikloheksanon : benzaldehida pada sintesis benziliden-sikloheksanon. Variasi rasio mol reaktan yang digunakan adalah sikloheksanon : benzaldehida 1:1,2:1,4:1,6:1, dan 8:1 menghasilkan rendemen benzilidensikloheksanon berturut-turut 4,54\%; 8,52\%; $9,95 \% ; \quad 12,73 \%$; dan $2,79 \%$.Rendemen maksimal yaitu pada rasio sikloheksanon : benzaldehida 6:1. Dari beberapa hasil penelitian tersebut, terbukti bahwa rasio mol reaktan berpengaruh terhadap jumlah produk. Oleh karena itu, dalam penelitian ini dilakukan variasi rasio mol reaktan pada sintesis senyawa 2-(4'-metoksibenziliden) sikloheksanon dari 4-metoksibenzaldehida dan sikloheksanon.

Pada sintesis organik, penggunaan irradiasi gelombang mikro dalam proses sintesis mampu menghasilkan produk dengan cepat serta rendemen yang tinggi (Liu \& Zhang, 2011). Sekhon (2010) penggunaan teknologi microwave dapat mengurangi waktu reaksi kimia dengan pemanasan langsung dan merata. Metode Microwave Assisted Organic Synthesis (MAOS) merupakan metode sintesis menggunakan teknik pemanasan dengan memanfaatkan energi dari gelombang mikro (Kuhnert, 2002). Metode tersebut didasarkan pada prinsip Green Chemistry (Wardencki, Curylo, \& Namiesnik, 2005). Dari literatur di atas, maka dalam penelitian ini dilakukan sintesis 2-(4'-metoksibenziliden)sikloheksanon menggunakan metode Microwave Assisted Organic Synthesis (MAOS). 


\section{METODE PENELITIAN}

Alat yang digunakan dalam penelitian ini adalah krus, microwave oven, satu set alat rekristalisasi, KLT scanner, spektrofotometer inframerah dan spektrometer ${ }^{1} \mathrm{H}$ NMR.

Bahan yang digunakan dalam penelitian ini adalah senyawa 4-metoksibenzal-dehida p.a, sikloheksanon p.a, $\mathrm{NaOH}$, etanol p.a, kloroform p.a, n-heksana p.a, dan metanol p.a.

Prosedur penelitian sebagai berikut. Sebanyak 0,2 gram $(0,005 \mathrm{~mol}) \mathrm{NaOH}$ dimasukkan ke dalam krus kemudian ditambahkan dengan $2 \mathrm{~mL}$ pelarut etanol dan diaduk hingga larut. Sintesis pertama menggunakan rasio mol 4-metoksibenzaldehida:sikloheksanon 1:1. Sebanyak 0,49 gram $(0,005 \mathrm{~mol})$ sikloheksanon dan 0,68 gram $(0,005 \mathrm{~mol})$ 4-metoksibenzaldehida secara berturutturut ditambahkan ke dalam krus berisi $\mathrm{NaOH}$ diaduk hingga bercampur. Krus yang berisi campuran ditutup menggunakan aluminium foil dan diberi lubang sebagai jalur sirkulasi udara. Setelah itu menyalakan microwave oven SIGMATIC SMO-25SSG. Campuran dalam krus dimasukkan ke dalam microwave oven dalam waktu 120 detik. Krus berisi endapan dikeluarkan dari microwave oven dan dibiarkan dalam suhu kamar. Setelah dingin krus berisi campuran ditimbang hingga berat konstan.
Prosedur diulang dengan mengganti rasio mol 4-metoksibenzaldehida:sikloheksanon 1:2, 1:4, 1:6, dan 1:8. Senyawa hasil sintesis diidentifikasi menggunakan KLT Scanner untuk menentukan kemurnian dan rendemen. Hasil sintesis dengan kemurnian tertinggi direkristalisasi dan dikarakterisasi menggunakan spektroskopi IR dan ${ }^{1} \mathrm{H}$ NMR.

\section{HASIL DAN PEMBAHASAN}

\section{Identifikasi Senyawa Hasil Sintesis dengan KLT dan KLT Scanner}

Hasil sintesis senyawa 2-(4'-metoksibenziliden)sikloheksanon berupa serbuk berwarna kuning. Data hasil sintesis disajikan pada Tabel 1. Senyawa hasil sintesis diidentifikasi menggunakan kromatografi lapis tipis (KLT). Eluen yang digunakan adalah kloroform : n-heksana (3:2). Pada penelitian ini dilakukan peng-kelompokan produk menjadi produk I dan produk II. Pengelompokan dilakukan berdasarkan nilai $\mathrm{R} f$ yang bersebelahan. Berdasarkan pengelompokan tersebut, produk I memiliki nilai $\mathrm{R} f$ yang lebih tinggi dibandingkan nilai $\mathrm{R} f$ produk II, sehingga produk I bersifat lebih nonpolar daripada produk II.

Berdasarkan hasil KLT scanner, produk I memiliki pola puncak kromatogram yang hampir sama dengan senyawa pembanding 2,6-bis-(4'-metoksibenziliden)sikloheksanon. Sedangkan produk II memiliki 
Jurnal Penelitian Saintek, Vol. 22, Nomor 1, April 2017

Tabel 1

Data senyawa pembanding dan hasil sintesis

\begin{tabular}{|c|c|c|c|c|c|c|c|c|}
\hline \multirow[b]{2}{*}{$\begin{array}{c}\text { Kode } \\
\text { sampel }\end{array}$} & \multirow{2}{*}{$\begin{array}{c}\text { Rasio } \\
\text { Mol } \\
\text { (M:S) }\end{array}$} & \multirow{2}{*}{$\begin{array}{c}\text { Berat } \\
\text { Hasil } \\
\text { (g) }\end{array}$} & \multicolumn{4}{|c|}{ Produk I } & \multicolumn{2}{|c|}{ Produk II } \\
\hline & & & $\mathrm{R} f$ & $\begin{array}{c}\text { Kemurnian } \\
(\%)\end{array}$ & Rendemen & $\mathrm{R} f$ & $\begin{array}{c}\text { Kemurnian } \\
(\%)\end{array}$ & Rendemen \\
\hline $\bar{X}$ & $2: 1$ & 1,993 & $\overline{0,65}$ & 57,57 & 68,705 & - & - & - \\
\hline A & $1: 1$ & 1,446 & 0,65 & 67,95 & 58,836 & - & - & 0 \\
\hline B & $1: 2$ & 1,908 & 0,65 & 27,99 & 31,979 & 0,57 & 33,55 & 59,272 \\
\hline $\mathrm{C}$ & $1: 4$ & 2,806 & 0,69 & 7,16 & 12,03 & 0,59 & 24,68 & 64,122 \\
\hline D & $1: 6$ & 2,662 & 0,73 & 3,47 & 5,531 & 0,63 & 18,98 & 46,782 \\
\hline E & $1: 8$ & 1,780 & 0,78 & 4,87 & 5,190 & 0,68 & 27,64 & 45,555 \\
\hline
\end{tabular}

Keterangan: $\mathrm{M}=4$-metoksibenzaldehida, $\mathrm{S}=$ Sikloheksanon, $\mathrm{X}=$ Senyawa pembanding 2,6-bis-(4'-metoksibenziliden)sikloheksanon

perbedaan. Sehingga diperkirakan produk II merupakan senyawa target. Hasil ini masih perlu dianalisis lebih lanjut dengan spektroskopi IR dan ${ }^{1} \mathrm{H}$ NMR. Produk II dengan kadar tertinggi yaitu sampel B direkristalisasi untuk karakterisasi lebih lanjut. Berdasarkan hasil KLT scanner sampel $\mathrm{B}$, setelah direkristalisasi kadar produk II pada sampel B meningkat menjadi 83,81\%.

\section{Identifikasi Senyawa Hasil Sintesis dengan Spektroskopi IR}

Hasil karakterisasi sampel B menggunakan spektrofotometer inframerah disajikan pada Gambar 1.

Berdasarkan spektrum IR senyawa hasil sintesis pada Gambar 1 dapat diidentifikasi bahwa terdapat serapan kuat pada daerah $2931,80 \mathrm{~cm}^{-1}$ yang menunjukan adanya gugus C-H alkana. Serapan pada daerah $1597,06 \mathrm{~cm}^{-1}$ dengan intensitas kuat yang merupakan serapan khas $\mathrm{C}=\mathrm{O}$ karbonil. Pada umumnya serapan gugus $\mathrm{C}=\mathrm{O}$ pada senyawa keton berada pada daerah sekitar $1715 \mathrm{~cm}^{-1}$ tetapi berdasarkan hasil, daerah serapannya bergeser ke daerah serapan yang lebih rendah (Silverstein, Webster, \& Kiemle, 2005). Pergeseran tersebut dapat terjadi karena adanya pengaruh lingkungan gugus $\mathrm{C}=\mathrm{O}$ yang menyebabkan penurunan daerah serapan. Adanya konjugasi dengan sebuah ikatan $\mathrm{C}=\mathrm{C}$ menyebabkan adanya pergeseran daerah serapan lebih rendah dan konjugasi lebih lanjut akan menghasilkan sedikit lagi penurunan daerah serapan. Serapan pada daerah $1512,19 \mathrm{~cm}^{-1}$ dan $1458,18 \mathrm{~cm}^{-1}$ menunjukan adanya gugus $\mathrm{C}=\mathrm{C}$ aromatik. Serapan pada daerah 1249,87 dan $1033,85 \mathrm{~cm}^{-1}$ menunjukan adanya gugus C-O eter. Serapan pada daerah 833,25 $\mathrm{cm}^{-1}$ menunjukan adanya aromatik tersubtitusi para. Hasil karakterisasi tersebut 


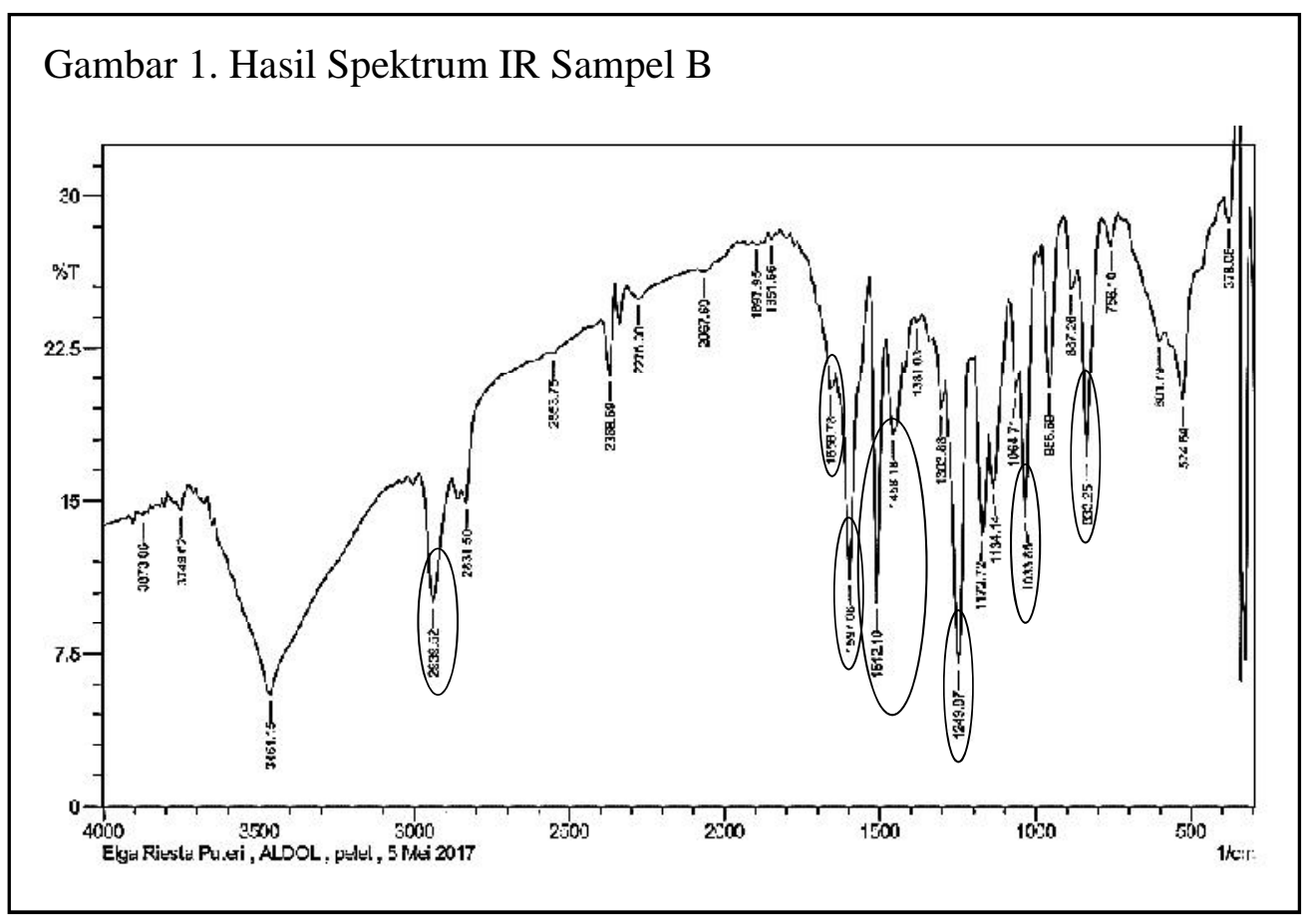

menunjukan bahwa senyawa hasil sintesis dapat berupa 2-(4'-metoksibenziliden) sikloheksanon ataupun 2,6-bis-(4'-metoksibenziliden)sikloheksanon. Hal ini disebabkan gugus fungsi yang dimiliki kedua senyawa sama. Dengan demikian perlu dilakukan identifikasi lebih lanjut menggunakan spektroskopi ${ }^{1} \mathrm{H}$ NMR.

\section{Identifikasi Senyawa Hasil Sintesis dengan Spektroskopi ${ }^{1} \mathrm{H}$ NMR}

Hasil karakterisasi sampel B menggunakan spektrometer ${ }^{1} \mathrm{H}$ NMR disajikan pada Gambar 2. Kode posisi proton senyawa target 2-(4'-metoksi-benziliden) sikloheksanon yang disajikan pada Gambar 3 dan hasil analisis spektrum ${ }^{1} \mathrm{H}$ NMR senyawa target disajikan pada Tabel 2.
Kode posisi proton senyawa hasil samping 2,6-bis-(4'-metoksibenziliden)sikloheksanon disajikan pada Gambar 4 dan hasil karakterisasi puncak-puncak yang muncul pada spektrum ${ }^{1} \mathrm{H}$ NMR selain puncak-puncak senyawa target diperkira-

Gambar 3. Kode posisi proton senyawa target 2-(4'-metoksibenziliden)sikloheksanon

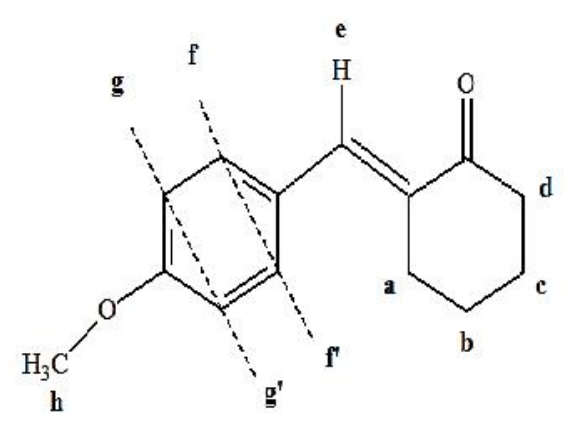




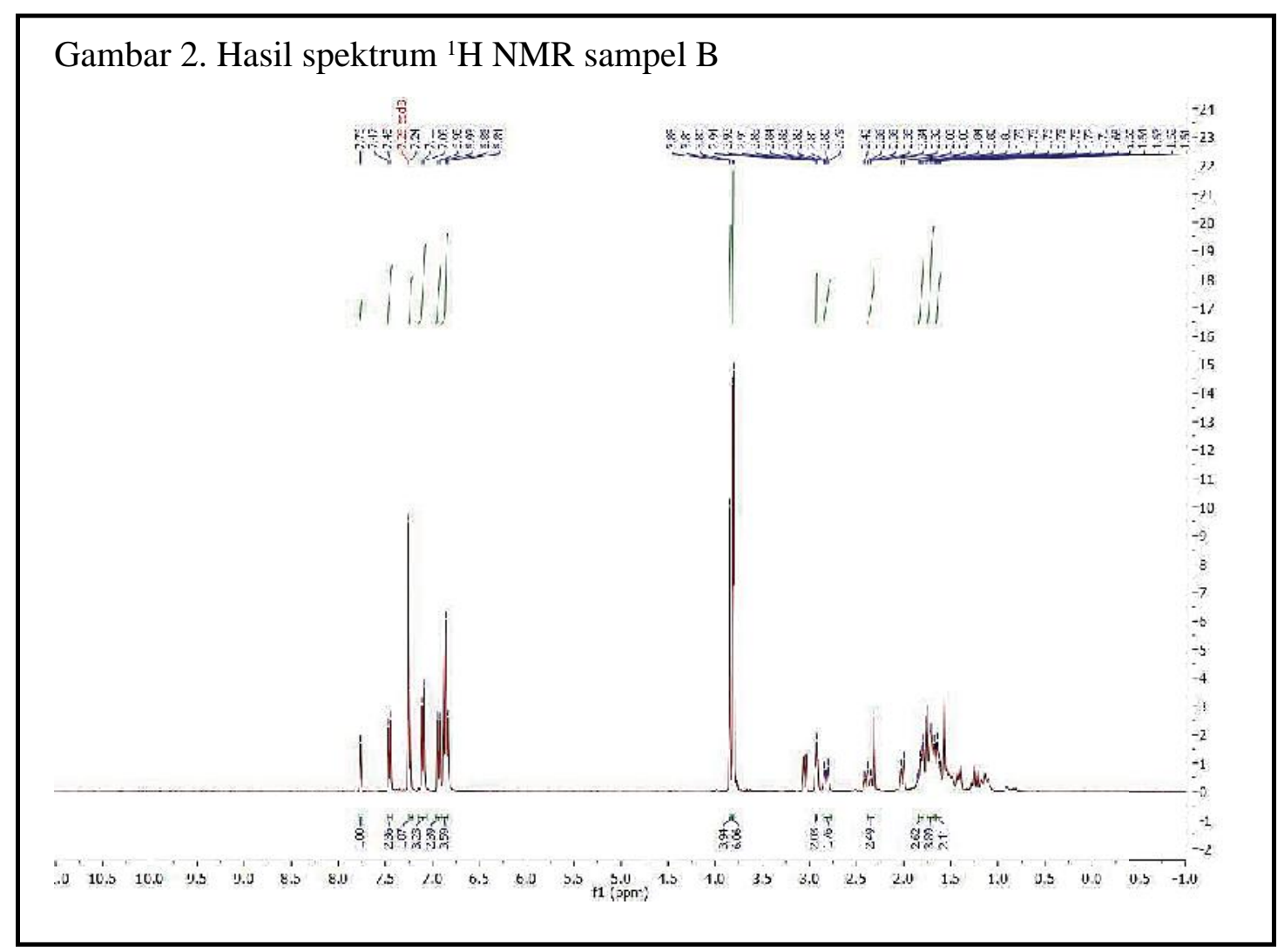

Tabel 2

Hasil Analisis Spektrum ${ }^{1}$ H NMR Senyawa Target Pada Sampel B

\begin{tabular}{cccccc}
\hline Kode & $\begin{array}{c}\text { Chemdraw } \\
\delta(\mathrm{ppm})\end{array}$ & $\begin{array}{c}\text { Target } \\
\delta(\mathrm{ppm})\end{array}$ & $\Sigma \mathrm{H}$ & Multiplisitas & $\begin{array}{c}\text { Perkiraan } \\
\text { Proton }\end{array}$ \\
\hline $\mathrm{a}$ & 1,37 & 1,63 & 2 & $\mathrm{~m}$ & $-\mathrm{CH}_{2}^{-}$ \\
$\mathrm{b}$ & 1,96 & 1,72 & 4 & $\mathrm{t}$ & $\mathrm{CH}$ alkena \\
c & 7,38 & 7,24 & 2 & $\mathrm{~s}$ & $\mathrm{~d}$ aromatik \\
$\mathrm{d}, \mathrm{d}$ & 7,19 & 7,47 & 4 & $\mathrm{~d}$ & $\mathrm{CH}$ \\
$\mathrm{e}, \mathrm{e}$ & 6,72 & 6,95 & 4 & $\mathrm{~d}$ & $-\mathrm{OCH}_{3}$ \\
$\mathrm{f}$ & 3,73 & 3,80 & 6 & $\mathrm{~s}$ & \\
\hline
\end{tabular}

kan adalah senyawa hasil samping disajikan pada Tabel 3.

Berdasarkan spektrum $\quad{ }^{1} \mathrm{H} \quad \mathrm{NMR}$ senyawa hasil pada Gambar 2 diketahui bahwa muncul puncak-puncak serapan selain puncak-puncak senyawa target 2-(4'-metoksibenziliden)sikloheksanon sehingga diperkirakan senyawa hasil sintesis masih berupa senyawa campuran. Senyawa lain yang teridentifikasi diperkirakan adalah 


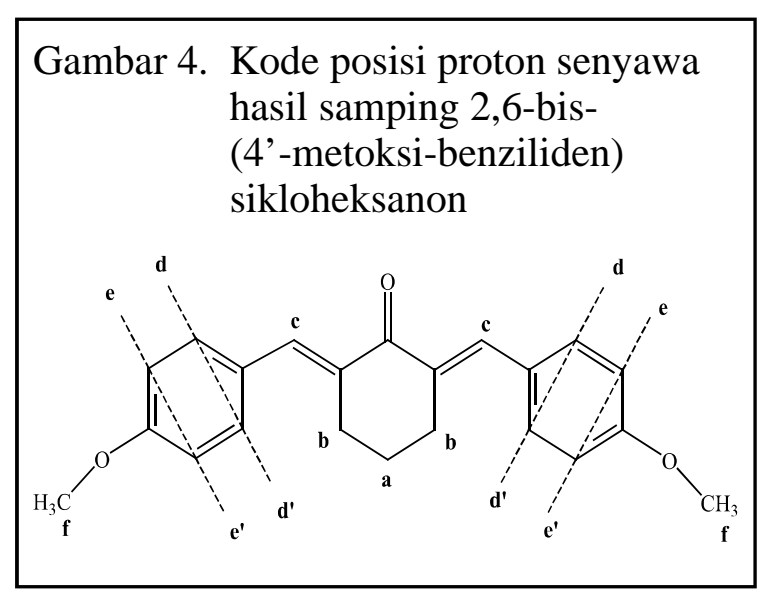

hasil samping berupa senyawa 2,6-bis-(4'metoksi-benziliden)sikloheksanon. Hal tersebut ditunjukan dengan adanya serapan khas dari proton metoksi $\left(-\mathrm{OCH}_{3}\right)$ yang muncul lebih dari satu puncak serta puncakpuncak lain yang mendukung. Selain itu muncul puncak-puncak kecil pada daerah sekitar 1 ppm yang diperkirakan adanya sisa bahan sikloheksanon atau hasil reaksi self-aldol condensation antarsikloheksanon dalam suasana basa.

\section{Reaksi Kondensasi Claissen Schmidt antara 4-Metoksibenzaldehida dengan} Sikloheksanon

Pada sintesis 2-(4'-metoksibenziliden) sikloheksanon terjadi reaksi kondensasi aldol silang antara sikloheksanon dan 4-metoksibenzaldehida dengan katalis basa kuat $\mathrm{NaOH}$. Reaksi ini berlangsung dalam suasana basa sehingga mengalami mekanisme enolat. Mekanisme reaksi sintesis 2-(4'-metoksibenziliden)sikloheksanon ditunjukkan pada Gambar 5.

Senyawa 2-(4'-metoksibenziliden)sikloheksanon yang dihasilkan masih memiliki $\mathrm{H} \alpha$ dapat mengalami reaksi lebih lanjut melalui serangan ion - $\mathrm{OH}$ terhadap $\mathrm{H} \alpha$ pada 2-(4'-metoksibenziliden)sikloheksanon membentuk ion enolat. Ion enolat menyerang gugus karbonil pada 4-metoksibenzaldehida membentuk ion alkoksida. Selanjutnya terjadi pembentukan aldol dilanjutkan dehidrasi dan terbentuk

Tabel 3

Hasil Analisis Spektrum ${ }^{1}$ H NMR Senyawa Hasil Samping pada Sampel B

\begin{tabular}{cccccc}
\hline Kode & $\begin{array}{c}\text { Chemdraw } \\
\delta(\mathrm{ppm})\end{array}$ & $\begin{array}{c}\text { Target } \\
\delta(\mathrm{ppm})\end{array}$ & $\Sigma \mathrm{H}$ & Multiplisitas & $\begin{array}{c}\text { Perkiraan } \\
\text { Proton }\end{array}$ \\
\hline $\mathrm{a}$ & 1,37 & 1,63 & 2 & $\mathrm{~m}$ & $-\mathrm{CH}_{2}-$ \\
$\mathrm{b}$ & 1,96 & 1,72 & 4 & $\mathrm{t}$ & $\mathrm{CH}$ alkena \\
$\mathrm{c}$ & 7,38 & 7,24 & 2 & $\mathrm{~s}$ & $\mathrm{CH}$ aromatik \\
$\mathrm{d}, \mathrm{d}$, & 7,19 & 7,47 & 4 & $\mathrm{~d}$ & $-\mathrm{OCH}_{3}$ \\
$\mathrm{e}, \mathrm{e}$, & 6,72 & 6,95 & 4 & $\mathrm{~d}$ & \\
$\mathrm{f}$ & 3,73 & 3,80 & 6 & $\mathrm{~s}$ & \\
\hline
\end{tabular}


Gambar 5. Mekanisme Reaksi Sintesis

2-(4'-metoksibenziliden)sikloheksanon dengan Katalis $\mathrm{NaOH}$

a. Pembentukan ion enolat

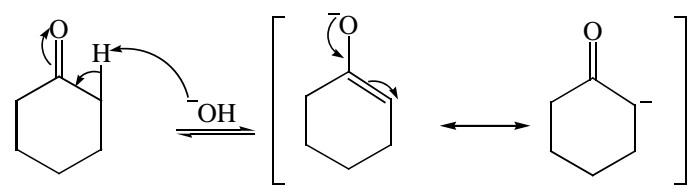

b. Serangan neuklofil

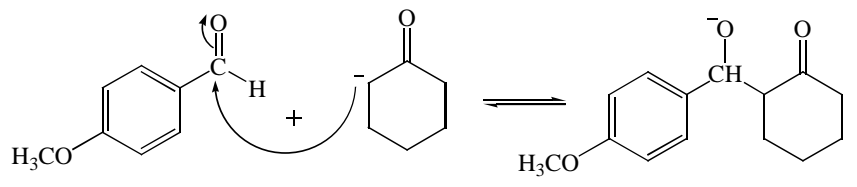

c. Pembentukan aldol dilanjutkan dehidrasi

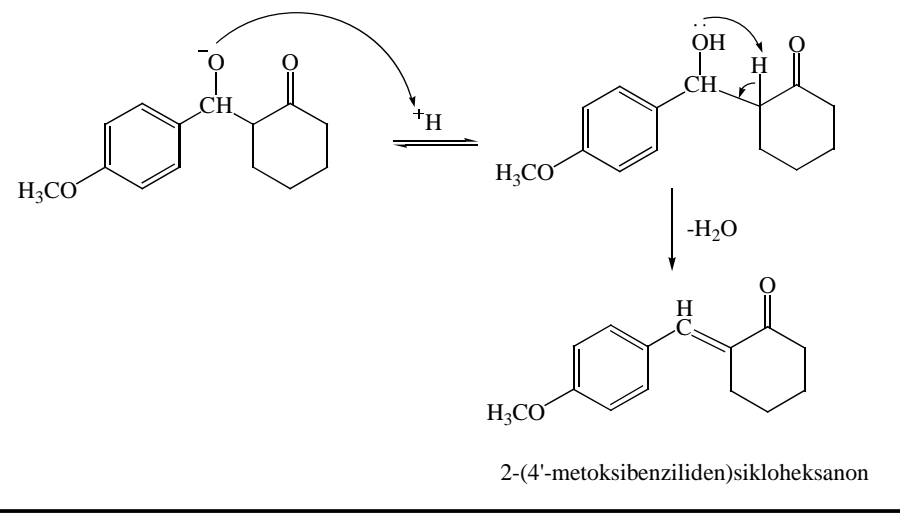

2-(4'-metoksibenziliden)sikloheksanon. Mekanisme reaksi terbentuknya 2,6-bis(4'-metoksibenziliden) sikloheksanon ditunjukkan pada Gambar 6.

Pengaruh Variasi Rasio Mol 4-Metoksibenzaldehida : Sikloheksanon pada Sintesis 2-(4'-Metoksibenziliden)sikloheksanon

Berdasarkan hasil penelitian, pada Tabel 1 dicantumkan bahwa terbentuk produk I dan produk II. Berdasarkan hasil identifikasi, dapat dijelaskan bahwa produk I merupakan 2,6-bis-(4'-metoksibenziliden)sikloheksanon dan produk II merupakan 2-(4'-metoksibenziliden)sikloheksanon. Produk pada setiap variasi rasio mol 4-metoksibenzaldehida : sikloheksanon dengan rendemen hasil disajikan pada Gambar 7.

Berdasarkan Tabel 1, diketahui bahwa rendemen2-(4'-metoksibenziliden) sikloheksanon maksimal pada rasio mol 4-metoksibenzaldehida : sikloheksanon (1:4) 
Gambar 6. Mekanisme Pembentukan Senyawa 2,6-bis-(4'metoksibenziliden)sikloheksanon

a. Pembentukan enolat
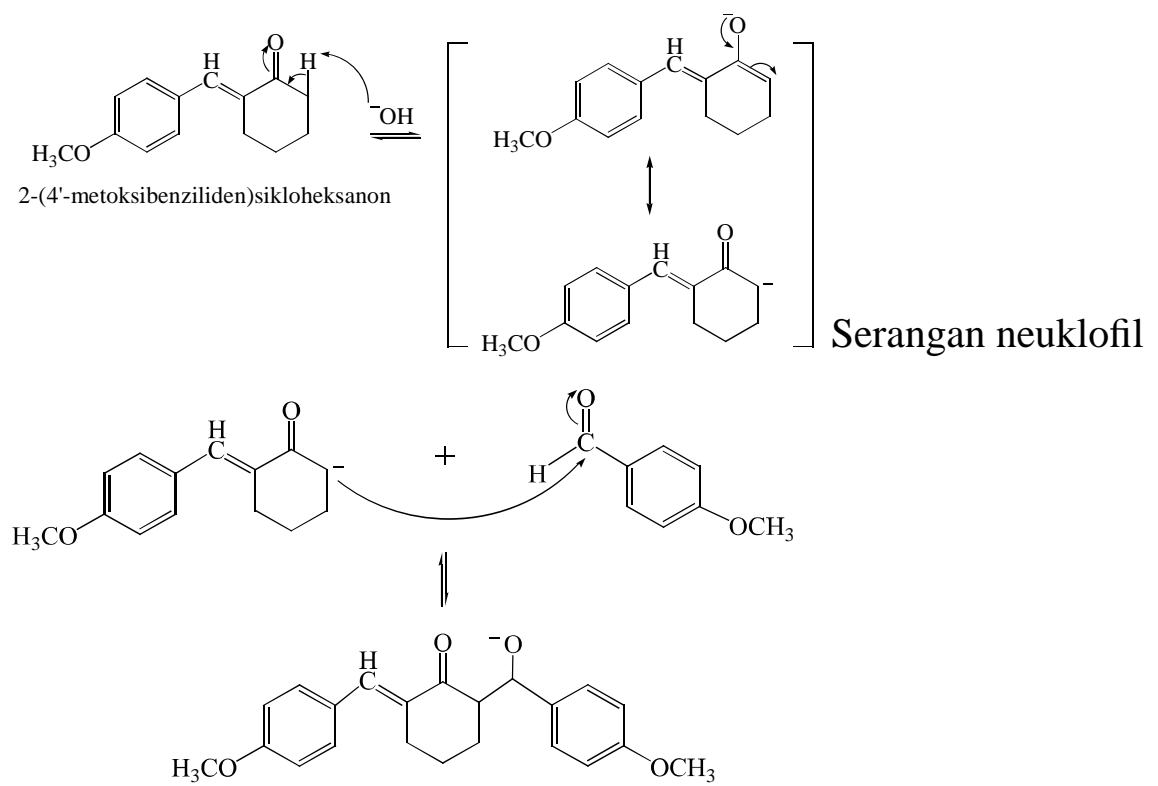

b. Pembentukan aldol dilanjutkan dehidrasi
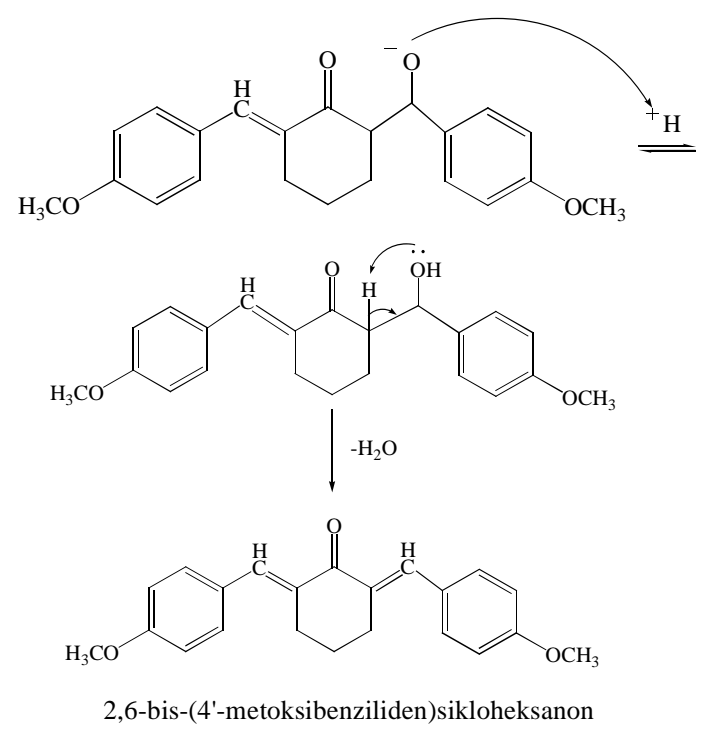

sebesar 64,122\%. Produk berupa serbuk berwarna kuning. Rendemen maksimal senyawa 2,6-bis-(4'-metoksibenziliden)sikloheksanon pada rasio mol 4-metoksi- benzaldehida : sikloheksanon (1:1) sebesar 58,836\%. Produk berupa serbuk berwarna kuning. Berdasarkan grafik hubungan rasio mol dengan rendemen 


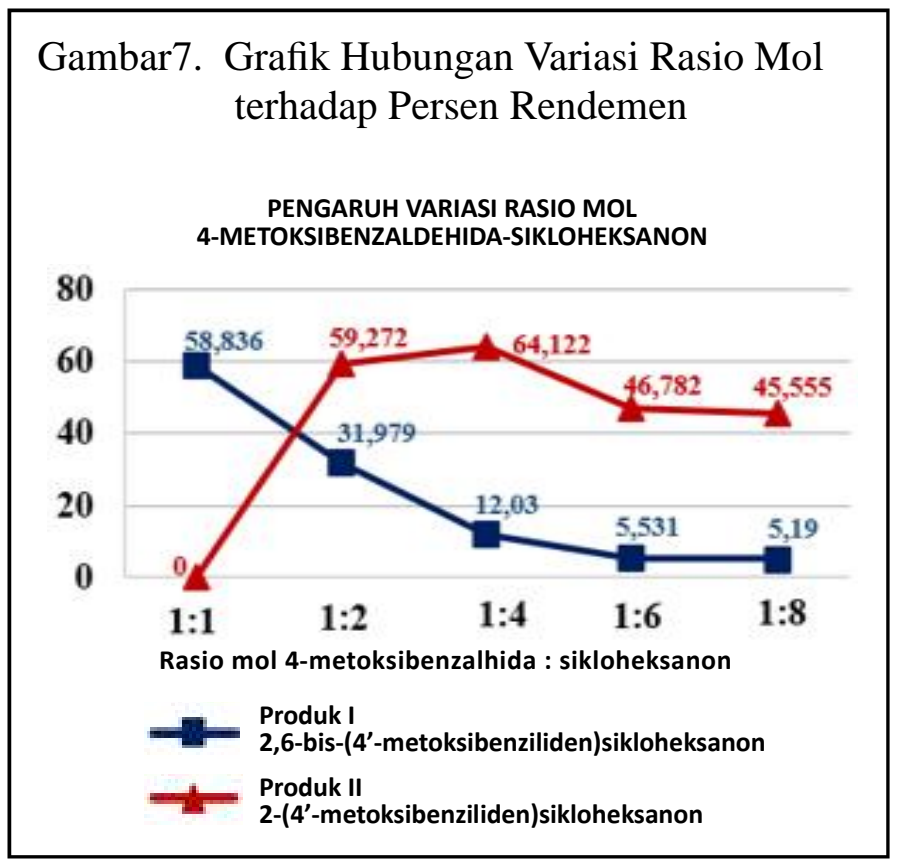

pada Gambar 7 dapat dijabarkan bahwa senyawa 2-(4'-metoksibenziliden)sikloheksanon tidak terbentuk pada rasio mol 4-metoksibenzaldehida : sikloheksanon (1:1) sedangkan secara teoritis seharusnya 2-(4'-metoksibenziliden)sikloheksanon dapat dihasilkan dengan menggunakan rasio mol tersebut. Pembentukan produk samping 2,6-bis-(4'-metoksibenziliden) sikloheksanon tidak dapat dihindari karena senyawa 2-(4'-metoksibenziliden) sikloheksanon hasil sintesis masih memiliki $\mathrm{H} \alpha$. Senyawa 2-(4'-metoksibenziliden) sikloheksanon dapat bereaksi kembali dalam suasana basa membentuk 2,6-bis(4'-metoksibenziliden)-sikloheksanon. Oleh karena itu, penambahan jumlah sikloheksanon dapat mengurangi pembentukan hasil samping senyawa 2,6-bis- (4'-metoksibenziliden)-sikloheksanon. Senyawa 2-(4'-metoksi-benziliden) sikloheksanon bersifat lebih polar jika dibandingkan dengan 2,6-bis-(4'-metoksibenziliden)sikloheksanon. Nilai $\mathrm{R} f$ 2-(4'-metoksibenziliden) sikloheksanon lebih rendah dibandingkan dengan 2,6-bis(4'-metoksibenziliden)sikloheksanon.

$$
\text { Rendemen senyawa 2-(4'-metoksi- }
$$
benziliden)sikloheksanon mengalami peningkatan dari rasio mol 4-metoksibenzaldehida : sikloheksanon 1:1 hingga 1:4 kemudian mengalami penurunan pada rasio mol 1:6 hingga 1:8. Dengan demikian, rasio mol 4-metoksibenzaldehida : sikloheksanon yang menghasilkan rendemen maksimal adalah 1:4. Peningkatan rendemen hasil terjadi karena pada sintesis senyawa 2-(4'-metoksibenziliden)sikloheksanon, 
bahan sikloheksanon yang digunakan berlebih sehingga pembentukan hasil samping dapat diminimalisir. Namun, penggunaan sikloheksanon berlebih juga memungkinkan terjadi reaksi self-aldol condensation atau produk sintesis yang dihasilkan masih terdapat sisa sikloheksanon. Secara teori, reaksi yang dapat terjadi karena penggunaan keton berlebih dalam suasana basa adalah reaksi kondensasi aldol antar senyawa keton (self-aldol condensation). Pada reaksi ini, sikloheksanon bertindak sebagai elektrofil dan neuklofil dalam suatu reaksi kondensasi aldol. Produk berupa $\beta$-hidroksiketon dapat mengalami dehidrasi membentuk keton tak jenuh $\alpha, \beta$ jika dilakukan pemanasan produk adisi aldol (Bruice, 2007). Produk ini diperkirakan muncul pada spektrum ${ }^{1} \mathrm{H}$ NMR di daerah sekitar 1 hingga 2 ppm pada Gambar 2 (Pavia, Lampman, Kriz, \& Vyvyan., 2001).

Reaksi lain yang mungkin terjadi adalah reaksi Cannizzaro. Bahan 4-metoksibenzaldehida yang digunakan dalam sintesis merupakan senyawa aldehida aromatik yang tidak memiliki $\mathrm{H} \alpha$ sehingga dapat mengalami reaksi Cannizzaro jika direaksikan dengan basa kuat. Putri (2009) berhasil melakukan reaksi Cannizzaro 4-metoksibenzaldehida tanpa pelarut dengan basa $\mathrm{KOH}$ menghasilkan asam 4-metoksibenzoat dan (4-metoksifenil)metanol.

\section{SIMPULAN}

Senyawa 2-(4'-metoksibenziliden)sikloheksanon dapat disintesis dari senyawa 4-metoksibenzaldehida dan sikloheksanon dengan katalis $\mathrm{NaOH}$ menggunakan metode MAOS dengan waktu reaksi 120 detik. Variasi rasio mol 4-metoksibenzaldehida : sikloheksanon berpengaruh terhadap rendemen hasil yang dihasilkan. Rendemen rasio mol 4-metoksibenzaldehida:sikloheksanon 1:1, 1:2, 1:4, 1:6, dan 1:8 secara berurutan adalah 0\%; 59,272\%; 64,122\%; $46,782 \%$; dan 45,555\%. Rasio mol 4-metoksibenzaldehida:sikloheksanon yang menghasilkan rendemen 2-(4'-metoksibenziliden)sikloheksanon maksimal adalah $1: 4$.

\section{DAFTAR PUSTAKA}

Budimarwanti. (2009). Penyediaan senyawa berkhasiat obat secarasintesis dengan analisis retrosintesis. Prosiding Seminar Nasional Penelitian, Pendidikan dan Penerapan MIPA. FMIPA UNY, Yogyakarta.

Bruice, P. Y. (2007). Organic chemistry (5 ed.). USA: Pearson Prentice Hall.

Handayani, S., \& Arty, I. S. (2008). Synthesis of hydroxyl radical scavengersfrom benzalacetone and its derivatives, Journal of Physical Science, 19(2), 6168.

Kuhnert, N. (2002). Microwave-assisted reactions in organic synthesis-are there 
any non-thermal microwave effects? Angew. Chem. Int. Ed., 41(11), 18631866.

Liu, H., \& Zhang, L. (2011). Microwave heating in organic synthesis and drug discovery. Shanghai: State Key Laboratory of Drug Research, Shanghai Institute of Materia Medica, Chinese Academy of Sciences.

Nurcahyo, A. D. (2014). Pengaruh Variasi rasio mol sinamaldehida-aseton pada sintesis 6-fenil-3,5-heksadien-2-on (Sinamalaseton) menggunakan metode MAOS (Microwave Assisted Organic Synthesis) (Skripsi tidak diterbitkan). FMIPA UNY, Yogyakarta.

Pavia, D. L., Lampman, G. M., Kriz, G. S., \& Vyvyan, J. R. (2001). Introduction to spectroscopy. Philadelphia: Sauders College.

Putri, S. A. (2009). Aplikasi reaksi canizzaro terhadap benzaldehida dan
p-Anisaldehida dengan kondisi tanpa pelarut (Skripsi tidak diterbitkan). FMIPA UNS, Surakarta.

Sekhon, B. S. (2010). Microwave-assisted pharmaceutical synthesis: An overview. International Journal of PharmTech Reasearch, 2(1), 827-833.

Silverstein, R. M., Webster, F. X., \& Kiemle D. J. (2005). Spectrometric identification of organic compounds $\left(7^{\text {th }}\right.$ ed.). New York: John Wiley \& Sons Inc.

Wardencki, W., Curylo, J., \& Namiesnik, J. (2005). Green chemistry-current and future issues. Polish Journal of Evironmental Studies, 14(4), 389-395.

Yuliyani, N. R. (2016). Pengaruh variasi rasio mol sikloheksanon-benzaldehida pada sintesis benzilidinsikloheksanon (Skripsi tidak diterbitkan). FMIPA UNY, Yogyakarta. 